\title{
Yield and fruit quality of two late-maturing Valencia orange tree varieties as affected by harvest date
}

\author{
loannis E. PAPADAKIs ${ }^{1 *}$, Eftichios E. ProtopaPADAKIS ${ }^{2}$, loannis N. THerIOs ${ }^{1}$
}

${ }^{1}$ Lab. Pomol., Sch. Agric., Aristotle Univ., 54124 Thessaloniki, Greece jpapad2004@yahoo.gr

${ }^{2}$ N.AG.RE.F., Olive Tree Subtrop. Plants Inst., 73100 Chania, Greece

\section{${ }^{*}$ Correspondence and reprints}

Received 26 February 2008 Accepted 10 June 2008

Fruits, 2008, vol. 63, p. 327-334 (c) 2008 Cirad/EDP Sciences All rights reserved DOI: $10.1051 /$ fruits:2008033 www.fruits-journal.org RESUMEN ESPAÑOL, p. 334

\section{Yield and fruit quality of two late-maturing Valencia orange tree varieties as affected by harvest date.}

Abstract - Introduction. Since citrus fruits are non-climacteric, commercial harvest for a given variety can occur over a prolonged period in the same orchard. Delayed citrus harvest has previously been reported to influence fruit quality variables during the current season and to reduce the subsequent year's yield. The aim of our study was to investigate the effect of harvest date on tree yield and fruit quality of two late-maturing Valencia orange varieties during two successive years. Materials and methods. One hundred 9-year-old Campbell and Lue Gim Gong Valencia orange trees budded on Swingle citrumelo rootstock were used. Fruit sampling included fruit harvest at five monthly intervals (April-August) during 2003, and only one harvest date (20 June) during 2004. Results and discussion. Based on seasonal variation of various fruit quality variables during the five harvests conducted in 2003, the most stable fruit quality variables were fruit weight, number of seeds per fruit, rind thickness, juice content and soluble solids content. In general, both varieties produced fruit with similar internal quality characteristics. However, their mean fruit weight differed in 2004 (Lue Gim Gong had larger fruit than Campbell). Furthermore, the annual and cumulative yields of Lue Gim Gong Valencia orange trees over two years were significantly higher than those of Campbell orange trees. Finally, the yield per tree and fruit quality of both varieties in 2003 and 2004 were not affected significantly by the date of harvest during 2003.

Greece / Citrus sinensis / variety trials / harvesting date / fruits / quality / yields / seasonal variation

\begin{abstract}
Qualité et rendement de la production de deux variétés tardives d'orangers Valencia, en liaison avec la date de récolte.

Résumé - Introduction. Les agrumes étant des fruits non-climatériques, la récolte d'arbres d'une même variété peut être effectuée sur une large période dans le même verger. Selon certains rapports, la récolte tardive des agrumes influencerait les variables de la qualité du fruit pendant la saison en cours et réduirait le rendement de l'année ultérieure. Le but de notre étude a été d'étudier l'effet de la date de récolte sur le rendement de l'arbre et la qualité du fruit pour deux variétés tardives d'orangers Valencia pendant deux années successives. Matériel et méthodes. Cent orangers Valencia appartenant aux variétés Campbell et Lue Gim Gong, âgés de 9 ans et greffés sur porte-greffe Swingle citrumelo, ont été utilisés. L'échantillonnage des fruits a porté sur cinq récoltes d'oranges effectuées mensuellement entre avril et août en 2003, et sur une seule récolte en 2004 (20 juin). Résultats et discussion. En se référant à la variation saisonnière de diverses variables de qualité du fruit au cours des cinq récoltes conduites en 2003, les caractéristiques les plus stables ont été le poids du fruit, le nombre de pépins par fruit, l'épaisseur de l'écorce, le contenu en jus, et la teneur en sucres. Globalement les deux variétés ont donné un fruit ayant des caractéristiques de qualité internes semblables. Cependant, le poids moyen de leur fruit a différé en 2004 : Lue Gim Gong a alors eu un plus gros fruit que Campbell. En outre, les rendements annuels et cumulatifs des orangers Lue Gim Gong sur deux ans ont été significativement meilleurs que ceux des orangers Campbell. En conclusion, le rendement par arbre et la qualité du fruit des deux variétés d'oranger étudiées en 2003 et 2004 n'ont pas été sensiblement affectés par la date des récoltes effectuées en 2003.
\end{abstract}

Grèce / Citrus sinensis / essai de variété / date de récolte / fruits / qualité / rendement / variation saisonnière 


\section{Introduction}

Since citrus fruits are non-climacteric, commercial harvest can occur over a prolonged period for a given variety in the same orchard. Delayed citrus harvest has previously been reported to influence fruit quality variables during the current season and reduce the subsequent year's yield [1, 2].

Valencia orange [Citrus sinensis (L.) Osbeck] is considered as one of the best and most popular late-maturing citrus varieties, prized for its high productivity and good juice quality. For these reasons, Valencia orange is the most widely cultivated citrus variety in the world. The most well-known clonal selections of Valencia orange are 'Cutter', 'Delta', 'Frost', 'Lue Gim Gong', 'Olinda', and the vigorous clone 'Campbell' [3]. In Greece, Valencia oranges grow successfully due to favorable climatic conditions. Furthermore, Swingle citrumelo [C. paradisi Macf. $\times$ Poncirus trifoliata (L.) Raf.] is the most adapted rootstock to the soil and climatic conditions of Crete, the southernmost Greek island. This rootstock has excellent resistance to tristeza, Phytophthora and citrus nematodes. Finally, fruit quality of orange scions budded on Swingle citrumelo is also excellent $[4,5]$.

In our study, Campbell and Lue Gim Gong orange scions budded on Swingle citrumelo were studied for two successive years under Greek environmental conditions to investigate: (i) whether tree yield and fruit quality variables of these varieties during the first year of the study (2003) were affected by the date of harvest over five monthly intervals, and (ii) whether harvest dates in the first year affect the tree yield and fruit quality variables measured at only one harvest in the second year (2004).

\section{Materials and methods}

\subsection{Plant material and growing conditions}

For our experiment, we used one hundred 9-year-old trees of Campbell and Lue Gim
Gong Valencia orange grown in an orchard located in the Nerokourou village of Chania (Crete, Greece). All the experimental plants were budded on Swingle citrumelo rootstock. Seeds of Swingle citrumelo were provided by the citrus plant section of the Olive Tree and Subtropical Plants Institute of Chania, and budwood from nucellar trees of Campbell and Lue Gim Gong growing in the orchards of the same institute was used. The mother plants of both varieties originated from budwoods imported from California in 1972.

The experimental trees were planted at a spacing of $4 \mathrm{~m} \times 5 \mathrm{~m}$ and grown under identical cultural and management practices. The soil of the orchard was classified as L (loamy) (39\% sand, 43\% silt, 18\% clay). It also contained $2 \%$ free $\mathrm{CaCO}_{3}$, and had a $\mathrm{pH}$ (soil:water, 1:2.5) value of 7.02, and an EC value of $2.7 \mathrm{dS} \cdot \mathrm{m}^{-1}$

The fertilization program applied was a soil application of approximately $100 \mathrm{~kg}$ $\mathrm{N} \cdot \mathrm{ha}^{-1}$ in the form of $\mathrm{Ca}\left(\mathrm{NO}_{3}\right)_{2}(19.5 \% \mathrm{Ca}$, $15.5 \% \mathrm{~N})$ in early spring, then foliar sprays of $8 \mathrm{~kg} \mathrm{~N} \cdot \mathrm{ha}^{-1}$ as $\mathrm{KNO}_{3}(36.5 \% \mathrm{~K}, 13.8 \% \mathrm{~N})$, divided into four equal doses during summer.

The orchard was drip-irrigated once a week, from May to September. In total, $500 \mathrm{~mm}$ of water were applied per year via irrigation. The area where the experimental orchard was located has an annual average rainfall of $810 \mathrm{~mm}$ occurring from October to April. The mean maximum temperature ranged from $23{ }^{\circ} \mathrm{C}$ in January to $36{ }^{\circ} \mathrm{C}$ in July, and the minimum temperatures from $2{ }^{\circ} \mathrm{C}$ to $14^{\circ} \mathrm{C}$, for the corresponding months. In the morning, the mean relative humidity varied between $55 \%$ and $80 \%$, and was inversely proportional to temperatures. All trees used in our study were free from virus and virus-like diseases.

\subsection{Experimental design and treatments}

Fifty trees from each of the two Campbell and Lue Gim Gong varieties were randomly selected in the experimental orchard. The trees of each variety were randomly divided into five groups (plots), each one with five 
replicates of two trees each. During 2003, five fruit harvest dates (treatments) were used, i.e., 14 April, 20 May, 17 June, 25 July and 26 August. On each harvest date, only fruit of one plot were collected. During 2004, fruit of all plots were harvested at the same time (20 June). The fruits of each replicate per plot were weighed immediately after harvest and fruit yield was recorded. Finally, tree size (height and canopy diameter) was measured on 20 June 2004. Canopy volume was evaluated by assuming the tree shape was a half of a prolate sphere. More specifically, tree size was computed using the formula $\mathrm{V}=0.524 \times b \times d^{2}$, where $b$ is the tree height and $d$ the average of the two diameters North-South and EastWest [6].

\subsection{Fruit quality variables}

On each harvest date, fruit samples were taken to determine some quality variables, i.e., mean fruit weight, rind thickness, soluble solids concentration, titratable acidity, juice content, vitamin $\mathrm{C}$ concentration and the number of seeds per fruit.

Fruit weight was determined using 20 randomly selected fruits per replicate. For the measurement of rind thickness, number of seeds per fruit and internal quality characteristics, twenty fruits per plot were used.

The juice of the fruit was extracted with the aid of an electric reamer. Thereafter, the concentration of soluble solids (SSC) of the juice was determined with a refractometer at $20^{\circ} \mathrm{C}$ (PR-1 digital refractometer Atago Co. Ltd., Japan), while the concentration of total acids (TA) was determined by titration with $0.1 \mathrm{~N} \mathrm{NaOH}$. Vitamin $\mathrm{C}$ (ascorbic acid) was determined by a modified version of the 2,6-dichloroindophenol method [7]. Finally, the ratio [SSC:TA] was calculated.

\subsection{Analysis of data}

The experimental design was a $2 \times 5$ factorial with two varieties and five treatments (harvest dates), with five two-tree replicates per treatment in 2003 , and a $2 \times 5$ factorial with two varieties and five treatments (based on harvest date of the previous year),

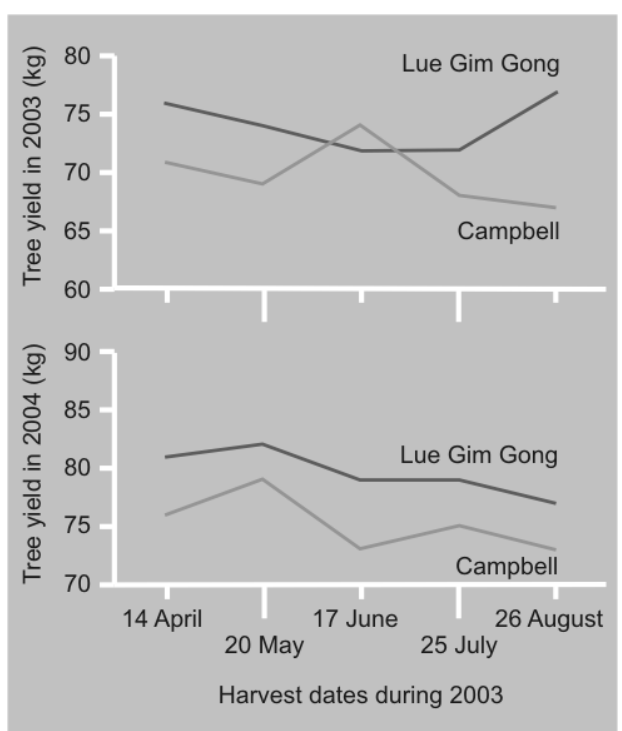

Figure 1.

Fruit yield per tree of Campbell and Lue Gim Gong Valencia orange varieties in the years 2003 and 2004. In 2003, mean yield per tree and per date of fruit harvest. In 2004, mean yield per tree and per harvest date of 2003, recorded at only one harvest conducted on 20 June 2004. For both harvest years, there were no significant differences between the two citrus varieties for the same harvest date.

with five two-tree replicates per treatment in 2004. The data were analyzed with the SPSS 11.0.1 for Windows statistical package (SPSS, Inc., Chicago, USA). Within the same variety, comparisons among the five harvest dates were made using Duncan's multiple range test $(P \leq 0.05)$. The mean values of all measurements of Campbell Valencia orange were compared with those of Lue Gim Gong Valencia orange using a $t$-test $(P \leq 0.05)$.

\section{Results}

In 2003, fruit yield of both varieties was not affected by harvest date over the five-month sampling period (figure 1). In 2004, where the fruits of all five treatments were harvested together on one date (20 June), there was no difference in fruit yield between treatments (figure 1).

The statistical analysis of the data regarding the various fruit quality variables (fruit weight, seeds per fruit, peel thickness and juice content per fruit, as well as the concentrations of vitamin C, soluble solids content and titratable acidity in the juice) revealed that, during 2003, within the same harvest date, there were no significant differences between the two varieties for any of these variables (figure 2). In addition, the 
Figure 2.

Seasonal pattern of various fruit quality variables of Campbell and Lue Gim Gong Valencia oranges sampled in five monthly intervals in 2003. Within the same harvest date, there were no significant differences between the two varieties for any of the variables.
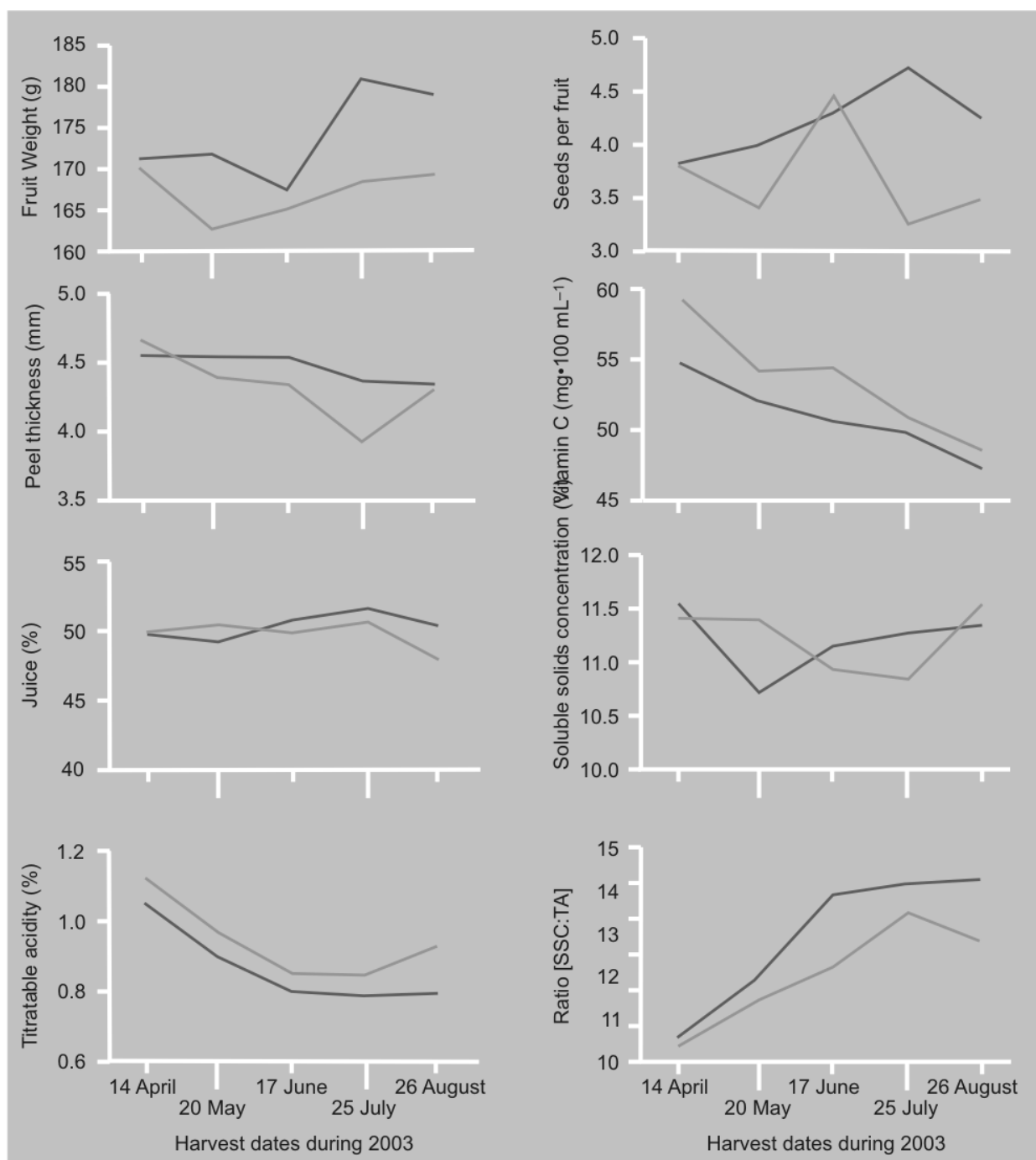

Harvest dates during 2003

Harvest dates during 2003

$$
\text { - Campbell — Lue Gim Gong }
$$

patterns of the seasonal variation of these fruit characteristics were similar for both varieties (figure 2).

No significant effects of the previous year's harvest date were observed in fruit quality variables measured in 2004 , and thus only mean values per variety are presented (table I). In this year (2004), significant differences between the two varieties were only observed regarding fruit weight: Lue Gim Gong's fruits were heavier than those of Campbell.
For all yield measurements, Lue Gim Gong had significantly higher values than Campbell. Nevertheless, canopy volume of both varieties was not significantly different (table II). In other words, although the two varieties did not differ from one another concerning canopy volume, not only tree yield in each of the two years and cumulative yield, but also the ratio between cumulative yield and canopy volume were significantly higher for Lue Gim Gong than for Campbell. 
Table I.

Physical and chemical characteristics of Campbell and Lue Gim Gong Valencia oranges harvested on 20 June 2004 (Greece).

\begin{tabular}{|c|c|c|c|c|c|c|c|c|}
\hline $\begin{array}{l}\text { Valencia } \\
\text { varieties }\end{array}$ & $\begin{array}{l}\text { Fruit weight } \\
\text { (g) }\end{array}$ & $\begin{array}{l}\text { Seeds } \\
\text { per fruit }\end{array}$ & $\begin{array}{l}\text { Peel } \\
\text { thickness } \\
(\mathrm{mm})\end{array}$ & $\begin{array}{c}\text { Juice } \\
(\%)\end{array}$ & $\begin{array}{c}\text { Vitamin C } \\
\text { (mg.100 } \mathrm{mL}^{-1} \text { of } \\
\text { juice) }\end{array}$ & $\begin{array}{c}\text { Soluble Solids } \\
\text { concentration (SSC) } \\
\text { (\%) }\end{array}$ & $\begin{array}{l}\text { Titratable } \\
\text { acidity (TA) } \\
(\%)\end{array}$ & [SSC:TA] \\
\hline Campbell & 174.7 & 5.0 & 4.2 & 48.3 & 55.4 & 10.8 & 1.1 & 9.8 \\
\hline Lue Gim Gong & 201.0 & 6.0 & 3.7 & 48.9 & 52.7 & 10.7 & 1.0 & 10.7 \\
\hline$t$-test & * & ns & ns & ns & ns & ns & ns & ns \\
\hline
\end{tabular}

\section{Table II.}

Yield and cumulative yield for the years 2003 and 2004, related to the tree canopy volume, for Campbell and Lue Gim Gong Valencia orange trees (Greece).

\begin{tabular}{|c|c|c|c|c|c|}
\hline $\begin{array}{l}\text { Valencia } \\
\text { varieties }\end{array}$ & $\begin{array}{l}\text { Yield } \\
(2003) \\
\text { (kg per tree) }\end{array}$ & $\begin{array}{l}\text { Yield } \\
(2004) \\
\text { (kg per tree) }\end{array}$ & $\begin{array}{l}\text { Total yield } \\
(2003 \text { and } 2004) \\
(\mathrm{kg} \text { per tree) }\end{array}$ & $\begin{array}{l}\text { Canopy volume } \\
\qquad\left(\mathrm{m}^{3}\right)^{1}\end{array}$ & $\begin{array}{l}\text { [Total yield:canopy volume] } \\
\qquad\left(\mathrm{kg} \cdot \mathrm{m}^{-3}\right)\end{array}$ \\
\hline Campbell & 69.8 & 75.2 & 145.0 & 22.4 & 6.47 \\
\hline Lue Gim Gong & 74.2 & 79.9 & 154.1 & 21.9 & 7.04 \\
\hline$t$-test & * & * & * & ns & * \\
\hline \multicolumn{6}{|c|}{ * Significant differences at $P \leq 0.05$; ns: non-significant differences. } \\
\hline \multicolumn{6}{|c|}{$\begin{array}{l}{ }^{1} \text { Tree size (height and canopy diameter) was measured on } 20 \text { June } 2004 \text {. Canopy volume was computed by assuming tree shape was } \\
\text { a half of a prolate sphere and using the formula } V=0.524 \times h \times d^{2} \text {, where } h \text { is the tree height and } d \text { the average of the two diameters } \\
\text { North-South and East-West [6]. }\end{array}$} \\
\hline
\end{tabular}

\section{Discussion}

Significant differences among different clones of Valencia orange grown under the same conditions have been reported for tree height, tree width, canopy volume, fruit production, yield efficiency and for some fruit quality variables $[8,9]$. In our study, the two varieties tested produced fruit with similar internal quality characteristics (table I, figure 2). However, the mean annual yield and cumulative yield per tree of Lue Gim Gong were significantly higher than those of Campbell (table II). Given that the trees were planted at a spacing of $5 \mathrm{~m} \times 4 \mathrm{~m}$ ( 500 trees per ha) in the orchard studied, the mean two-year cumulative yield per ha of Campbell Valencia orange trees was about
4.5 t lower than that of Lue Gim Gong Valencia orange trees. Also, the two varieties differed from one another with regard to yield efficiency calculated on a two-year basis: Lue Gim Gong had greater yield efficiency than Campbell. In 2003, fruit weight was similar for Lue Gim Gong and Campbell, while, in 2004, the fruits of Lue Gim Gong weighed more than those of Campbell (table II).

Fruit size is the main factor affecting the market price of Valencia fruit. The average weight per fruit of Campbell and Lue Gim Gong was much lower than that reported elsewhere for Campbell [10], but also for other Valencia varieties $[11,12]$. The causes leading to small fruit size in our study are not known. Some potential causes would be 
genetics, growing conditions, inflorescence type [13, 14], the number of seeds per fruit [15], plant growth regulators [16], sourcesink relationships [17], rootstock [12], number of fruits per tree, tree yield during the previous year, and some nutritional disorders. Macroscopic observations indicated that Campbell and Lue Gim Gong Valencia orange fruits are borne on different inflorescence types (leafy and leafless) in percentages which varied from variety to variety and from the first year to the second. Furthermore, the duration of flowering was less for Lue Gim Gong (26 d for 2002 and 25 d for 2003) than for Campbell (29 d for 2002 and $30 \mathrm{~d}$ for 2003). Cameron et al. [15] have also shown that the fruit size of Valencia oranges is related to the number of seeds, i.e., larger fruit contains more seeds than smaller fruit. In our study, Lue Gim Gong fruit tended to have more seeds than Campbell fruit (table I, figure 2). However, the statistical analysis of the seed data indicated that these differences between the two varieties were not significant.

The fruit quality variables (figure 2) could be broadly grouped into three categories: (i) fruit weight, number of seeds per fruit, peel thickness, juice content and SSC, (ii) vitamin $\mathrm{C}$ and TA, and (iii) maturity index ([SSC:TA] ratio). Although the variables of the first category remained almost unaffected during the harvesting period, those of the second and the third categories tended to decrease or increase, respectively. Similarly, Barry et al. [18] reported that the seasonal variation in SSC and TA of Valencia orange fruit was relatively small, but larger for TA than for SSC.

The most important finding of our experiment was that the time of fruit harvest during the first year (2003) had no negative effects on yield and/or quality of fruit in 2004. From a pomological point of view, a competition for carbohydrates and other substances between mature and developing fruit (sinks) provided by the leaves (sources) would be expected, especially when the fruit was harvested very late (July or August). However, the results indicate that such an antagonism did not take place. An explanation for this finding is that all the experimental trees were relatively young
(9 years old), were growing under favorable conditions, were vigorous and healthy, and were not suffering from any nutrient deficiency. Hilgeman et al. [1] reported that late harvest (July) in Arizona, compared with an early harvest (March), decreased yield in the following year. Stress from cropping in our study was likely much less than in Hilgeman's study [1], due to the fact that, in the present study, there were only about 350 fruits per tree, on trees close to $3 \mathrm{~m}$ tall with canopy volume close to $22 \mathrm{~m}^{3}$. Furthermore, in apple, dwarfing rootstocks often result in greater return bloom at similar crop loads, presumably because fewer resources are committed to vegetative growth. Compared with the vigorously vegetative trees used in Hilgeman's study, the more dwarfing Swingle citrumelo rootstock that we used in our experiment may have had similar effects in citrus.

\section{Conclusions and benefits to growers}

Both Campbell and Lue Gim Gong Valencia orange varieties produced fruit of marketable quality during the two years of our study (2003 and 2004). The ratio [SSC:TA], an index of organoleptic quality, indicates that the edible quality of both varieties' fruits was high. It is also worth mentioning that the juice content of fruit remained unaffected during the entire harvesting period in 2003 (April to August).

Harvesting Campbell and Lue Gim Gong Valencia orange fruits from April to August did not reduce the yield of the trees in the following year. It is also evident that the time of fruit harvest in one year did not significantly affect their quality (juice content, SSC, TA, [SSC:TA], vitamin $\mathrm{C}$ and number of seeds) during the following year.

When both varieties are budded on Swingle citrumelo rootstock, the cultivation of Lue Gim Gong Valencia orange would be potentially more profitable for citrus growers compared with Campbell Valencia orange. 


\section{References}

[1] Hilgeman R.H., Dunlap J.A., Sharp F.O., Effect of time of harvest of Valencia oranges in Arizona on fruit grade and size and yield the following year, Proc. Amer. Soc. Hort. Sci. 90 (1967) 103-109.

[2] Ramirez J.M., Krezdorn A.H., Effect of date of harvest and spot picking on yield and quality of grapefruit, Proc. Fla. Stn. Hortic. Soc. 88 (1975) 40-44.

[3] Saunt J., Citrus varieties of the world, an illustrated guide, Sinclair Int. Itd., Norwich, UK, 2000.

[4] Castle W.S., Wutcher H.K., Youtsey C.O., Pelosi R.R., Citrumelos as rootstock for Florida citrus, Proc. Fla. Stn. Hortic. Soc. 101 (1988) 28-33.

[5] Protopapadakis E., Voulgaropoulos A., Sofoniou M., Rootstocks affect leaf and fruit mineral concentrations of Washington navel orange, Fruits 53 (1988) 167-173.

[6] Turrell F.M., Tables of surfaces and volumes of spheres and of prolate and oblate spheroids and spheroidal coefficients, Univ. Calif. Press, Berkeley, USA, 1946.

[7] Horwitz W., Official methods of analysis of the association of analytical chemists (AOAC), 12th ed., Horwitz W. (Ed.), Washington, DC, USA, 1975.

[8] Cedenomaldonado A., Perezlopez A., Boneta E., Torres C.J., Effect of rootstocks on tree size and yield of 6 Valencia orange clones, J. Agric. Univ. Puerto Rico 78 (1994) 123-129.

[9] Kotsias D., Assessing budsports of Valencia sweet orange [Citrus sinensis (L.) Osbeck] for desirable characteristics, J. Am. Pomol. Soc. 54 (2000) 207-212.
[10] Economides C.V., The influence of rootstocks on tree growth, yield and fruit quality of Valencia oranges in Cyprus, J. Hortic. Sci. 52 (1977) 29-36.

[11] Barry G.H., Castle W.S., Davies F.S., Rootstocks and plant water relations affect sugar accumulation of citrus fruit via osmotic adjustment, J. Am. Soc. Hortic. Sci. 129 (2004) 881-889.

[12] Wutscher H.K., Bowman K.D., Performance of Valencia orange on 21 rootstocks in central Florida, HortScience 34 (1999) 622-624.

[13] Barry G.H., Castle W.S., Davies F.S., Juice quality of Valencia sweet oranges borne on different inflorescence types, HortScience 39 (2004) 33-35.

[14] Jahn O.L., Inflorescence types and fruiting patterns in Hamlin and Valencia oranges and Marsh grapefruit, Am. J. Bot. 60 (1973) 663670.

[15] Cameron J.W., Cole D. Jr., Nauer. E.M., Fruit size in relation to seed number in Valencia orange and some other citrus varieties, Proc. Am. Soc. Hortic. Sci. 76 (1960) 170-180.

[16] Goodwin P.B., Phytohormones and fruit growth, in: Letham D.S., Goodwin P.B., Higgins T.J.V. (Eds.), Phytohormones and related compounds: a comprehensive treatise, vol. 2, Elsevier, Amsterdam, Holland, 1978, pp. 175-204.

[17] Ho L.C., Metabolism and compartmentation of improved sugars in sink organs in relation to sink strength, Ann. Rev. Plant Physiol. 39 (1988) 335-378.

[18] Barry G.H., Castle W.S., Davies F.S., Littell R.C., Variability in juice quality of Valencia sweet orange and sample size estimation for juice quality experiments, J. Am. Soc. Hortic. Sci. 128 (2003) 803-808. 


\section{Calidad y rendimiento de la producción de dos variedades tardías de naranjos Valencia en relación con la fecha de cosecha.}

Resumen - Introducción. Dado a que los frutos cítricos son frutos no-climatéricos, se puede efectuar la cosecha de árboles de una misma variedad en un largo periodo en el mismo vergel. De acuerdo con ciertos informes, la cosecha tardía de los cítricos puede influenciar las variables de la calidad del fruto durante la estación en curso; y, puede asimismo reducir el rendimiento del año posterior. El objetivo de nuestra investigación fue el estudio del efecto de la fecha de la cosecha sobre el rendimiento del árbol y sobre la calidad del fruto para dos variedades tardías de naranjos Valencia durante dos años sucesivos. Material y métodos. Se emplearon cien naranjos Valencia pertenecientes a las variedades Campbell y Lue Gim Gong, de 9 años de edad e injertados en porta injertos Swingle citrumelo. El muestreo de los frutos se centró en cinco cosechas de naranjas que se efectuaron mensualmente entre abril y agosto de 2003, así como sobre una única cosecha de 2004 (20 de junio). Resultados y discusión. El peso del fruto, el número de pepitas por fruto, el grosor de la cáscara, el contenido en zumo, así como el contenido en azúcares fueron las características más estables con referencia a la variación estacional de diversas variables de la calidad del fruto en el transcurso de las cinco cosechas realizadas en 2003. De modo general, ambas variedades dieron un fruto con características cualitativas internas semejantes. No obstante, el peso medio de su fruto difirió en 2004: Lue Gim Gong tuvo aquí un fruto más grande que Campbell. Asimismo los rendimientos anuales y cumulativos de los naranjos Lue Gim Gong en dos años fueron significativamente mejores que aquellos de los naranjos Campbell. En conclusión, el rendimiento por árbol y la calidad del fruto de ambas variedades de naranjo estudiadas en 2003 y 2004 no se afectaron sensiblemente por la fecha de las cosechas realizadas en 2003.

Grecia / Citrus sinensis / ensayos de variedades / fecha de recolección / frutas / calidad / rendimiento / variación estacional 